\title{
Penerapan Metode Diskusi Kelompok Pada Pembelajaran Daring Di Masa Pandemi Covid 19
}

\author{
Muhammad Badrul Tamam \\ E-mail : m.badrultamamm@gmail.com \\ Program Studi Pendidikan Bahasa dan Sastra Indonesia. Universitas Riau
}

\section{Pengantar}

Dalam pendidikan, metode pembelajaran merupakan hal yang amat penting saat proses pembeajaran di kelas. Keberhasilan atau tercapai nya tujuan pembelajaran sebagian besar bergantung pada metode pembelajaran yang di gunakan oleh pendidik saat mengajar dikelas. Kita ketahui bahwa pada masa pandemi covid 19 ini, pembelajaran dilakukan secara daring atau belajar dari rumahnya masing- masing dengan teknologi yang terhubung dengan internet tanpa perlu pergi ke sekolah. Pembelajarang daring ini ditetapkan oleh pemerintah bertujuan untuk memutus rantai penyebaran virus corona dan juga supaya pendidik dan siswa terhindar dari virus corona ini, karena penyakit ini dapat ditular melalui komunikasi secara langsung atau tatap muka.

Metode pembelajaran adalah cara yang digunakan untuk mengimplementasikan rencana yang sudah disusun dalam kegiatan nyata agar tujuan yang telah disusun tercapai secara optimal. Ini berarti metode digunakan untuk merealisasikan strategi yang telah ditetapkan. Keberhasilan implementasi strategi pembelajaran sangat tergantung pada cara pendidik menggunakan motode pembelajaran, karena suatu strategi pembelajaran hanya mungkin dapat diimplementasikan melalui penggunaan metode pembelajaran. Di masa pandemic ini, metode pembelajaran yang diterapkan oleh pendidik saat melakukan pembelajaran secara daring sangatlah menentukan bagaimanakah siswa dapat mengikuti pembelajaran secara maksimal atau tidak. Oleh karena itu, sebagai seorang pendidik hendaknya menggunakan metode pembelajaran yang efektif dan efesien dalam proses pembelajaran di kelas, salah satunya adalah metode diskusi.

Metode diskusi adalah metode belajar dengan cara membentuk perkumpulan kemudian mengadakan perbincangan ilmiah guna mengumpulkan pendapat, menarik data, membuat 
kesimpulan dan pemecahan suatu masalah. Metode ini dilakukan dengan minimal 2 peserta yang saling bertukar pendapat mengenai isu yang dibahas. Metode diskusi dianggap lebih interaktif sebab setiap individu diperbolehkan untuk mengutarakan pendapatnya.

Dilihat dari segi psikologis, metode diskusi juga memberikan dampak positif antara lain adalah menciptakan individu yang percaya diri, bertanggungjawab dan berani mempertahankan pendapatnya sendiri. Ketika mendapat sanggahan dari pihak lain mengenai argumennya, secara sadar mahasiswa mengerahkan segala pengetahuannya guna mempertahankan pendapatnya. Mempertahankan pendapat merupakan salah satu sikap tanggung jawab.

\section{Tindakan Yang Dilakukan}

Adapun beberapa hal yang dapat dilakukan atau dipersiapkan oleh pendidik dalam menerapkan Pembelajaran dengan Metode Diskusi di Kelas, yaitu sebagai berikut :

1. Kesiapan pendidik dan peserta didik.

2. Pendidik menjadi fasilitator atau pemandu jalannya diskusi.

3. Pendidik memberikan bahan materi yang akan didiskusikan

4. Siswa mencari sumber dari bahan materi yang diberikan oleh pendidik

5. Pendidik menyiapkan beberapa pertanyaan terkait materi yang akan dibahas, seperti materi puisi.

6. Kemudian pendidik menyampaikan pertanyaan yang telah disiapkan kepada siswa satu persatu dan langsung didiskusikan dan dicari jawaban yang paling tepat atas setiap pertanyaan.

7. Para peserta didik diperbolehkan secara aktif untuk menjawab setiap pertanyaan. Bagi siswa yang tidak aktif, pendidik bisa memanggil dan meminta pendapat atau tanggapan atas materi atau pertanyaan yang sedang di bahas. Hal ini agar seluruh siswa dapat berpatisipasi aktif saat pembelajaran berlangsung.

8. Dipertengahan atau diakhir diskusi, pendidik bisa memberikan kuis atau games yang menarik dan menyenangkan. Seperti games sambung puisi, tebak pencipta puisi, tebak struktur puisi, tebak judul puisi dan games lainnya. Hal ini supaya peserta didik tidak merasa bosan atau merasa tertekan saat proses diskusi berlangsung. 
9. Pendidik hendaknya memberikan penguatan, kesimpulan serta materi agar peserta lebih paham dan mengerti.

Sebagai pendidik hendaknya senantiasa memperhatikan jalannya diskusi, apakah diskusi tersebut berjalan dengan lancar atau tidak. Kemudian pendidik juga harus senantiasa memotivasi siswa untuk aktif dalam proses diskusi agar mendapatkan hasil yang maksimal saat pembelajaran di kelas. Dan ingat, dalam metode ini pendidik hanya sebagai fasilitator atau hanya memandu jalannya diskusi. Diharapkan saat diskusi berlangsung siswa terlibat aktif dalam proses dan hasilnya, seperti dalam mencari dan membuat bahan materinya serta pada saat presentasinya. Dengan demikian proses pembelajaran dapat tercapai secara maksimal.

\section{Sarana Pendukung}

Pembelajaran online merupakan proses pembelajaran yang sistem belajarnya dilakukan secara terbuka dan tersebar dengan menggunakan alat bantu yang membutuhkan jaringan internet atau teknologi yang berbasis jaringan agar dapat membantu proses belajar dan pemberian pengetahuan yang mengutamakan aksi dan interaksi antar pendidik dan siswa. Alat bantunya, seperti melalui aplikasi Zoom, Google Classroom, dan sebagainya (Novita Arnesi dan Abdul Hamid K, 2015).

Dalam penerapan metode diskusi secara daring ini, tentunya terdapat beberapa sarana pendukung yang perlu disiapkan demi ketercapaian pembelajaran dikelas secara maksimal. Adapun sarana pendukungnya sebagai berikut :

\section{Aplikasi Google Classroom}

2. Aplikasi Google Meet/Zoom

3. Aplikasi WhatsappA/Telegram

4. Bahan Materi

5. Latop/Hp

6. Kuota internet

7. Jaringan 


\section{Tindakan Solutif}

Dalam penerapan metode ini, tentunya terdapat beberapa hambatan yang tentunya akan menganggu kelancaran pada saat proses pembelajaran di kelas. Minsalnya saat proses pembelajaran dan sarana pendukung mengalami problem/masalah/halangan, seperti jaringan

yang kurang stabil, terdapat beberapa siswa yang tidak memiliki HP atau laptop, bahan materi yang sulit dicari dan siswa kurang aktif dalam proses pembelajaran. Tentunya ini akan menghambat kelancaran penerapan metode diskusi ini dalam pembelajaran dikelas.

Demi ketercapaian penerapan metode diskusi dalam proses pembelajaran ini secara maksimal, tentunya kita harus mencari solusi atas permasalahan atau hambatan tersebut demi kelancaran proses pembelajaran di kelas. Adapun beberapa solusi yang bisa diterapkan atau dilakukan untuk mengatasi permasalahan atau hambatan dalam proses penerapan metode diskusi ini, yaitu sebagai berikut :

1. Pendidik menyediakan bahan materi yang akan di pelajari atau dibahas oleh siswa. Baik berupa buku, $e$ - book, link website pembelajaran, aplikasi pembelajaran dan lainnya. Hal ini bertujuan agar memudahkan siswa dalam mencari bahan materi untuk di diskusikan.

2. Siswa yang tidak memiliki handphone atau laptop bisa pergi ke warnet atau meminjam Hp orang tua, saudara atau teman - temannya.

3. Agar dapat mengiktui proses pembelajaran secara maksimal, siswa bisa melakukan proses pembelajaran daring dengan mencari tempat yang jaringannya bagus atau tempat yang memiliki wifi gratis

4. Pendidik hendaknya senantiasa memperhatikan setiap siswa saat proses diskusi berlangsung. Bagi siswa yang tidak aktif, pendidik bisa memanggil dan meminta pendapat atau tanggapan atas materi atau pertanyaan sedang di diskusikan. Hal ini agar seluruh siswa dapat berpatisipasi aktif saat pembelajaran berlangsung.

\section{Simpulan}

Penerapan metode diskusi dalam pembelajaran daring di sekolah adalah salah satu usaha yang dapat dilakukan oleh pendidik untuk mencapai sebuah pembelajaran yang maksimal. 
Metode diskusi yang digunakan pada masa pandemi dan pembelajaran daring ini dirasa cukup efektif dan efesien. Karena sebagian besar siswa yang terlibat dalam pembelajaran mengambil bagian dalam menyampaikan tanggapan atau pendapatnya saat proses pembelajaran berlangsung, hal ini menunjukkan bahwa siswa tersebut menunjukkan sikap antusias dalam mengikuti pembelajaran tersebut. Siswa di minta untuk mendengarkan materi yang telah disampaikan kemudian memberikan komentar atau tanggapannya mengenai materi yang telah di sampaikan. Apabila ada siswa yang kurang aktif, pendidik bisa memanggil dan meminta pendapat atau tanggapan atas materi atau pertanyaan yang sedang dibahas. Oleh karena itulah, penerapan metode diskusi dalam pembelajaran daring ini di nilai cukup bagus untuk diterapkan dalam proses pembelajaran.

\section{Referensi}

Ade Kusmana. 2011. E-learning dalam Pembelajaran. Jurnal Lentera Pendidikan, 14 (1) hal 38

Aryuna \& Syahidul. 2021. Sarana Dan Prasarana Dalam Mendukung Pembelajaran Daring Pada Masa Pandemi Covid-19. Jurnal Inspirasi Manajemen Pendidikan, 09 (1). Hal 189 - 192

Retno Andini. 2020. Penerapan Metode Ceramah Dan Diskusi Selama Pembelajaran Online. dari file://C:/Users/HP/Downloads/MAKALAH\%20-

\%20PENERAPAN\%20METODE\%20CERAMAH\%20DAN\%20DISKUSI\%20SELAMA\%20P EMBELAJARAN\%20ONLINE.pdf. diakses pada tangal 3 Desember 2021

Zulhafizh, Atmazaki, \& Syahrul R. (2013). "Kontribusi Sikap dan Motivasi Belajar Siswa terhadap Hasil Belajar Bahasa Indonesia”. Jurnal Bahasa, Sastra dan Pembelajaran, 1(2), 13-28.

Zulhafizh. 2020. "Membina Aktifitas Belajar Mahasiswa di Perguruan tinggi Melalui Metode TIE (Translation, Interpretation, Extrapolation) pada Masa Pandemi Covid-19”. Jurnal kependidikan, 6 (3): 502-511.

Nurul Malahayanti. 2021. Metode Daring Dalam Pembelajaran Daring, Efektifkah?. dari https://serikatnews.com/metode-diskusi-ketika-daring-efektifkah/. diakses pada tanggal 3 Desember 2021. 
Evan Nafis. 2021. Efektivitas Metode Diskusi Dalam Pembelajaran Jarak Jauh Untuk Mata Pelajaran Pendidikan Agama Islam Jenjang Siswa Sekolah Menengah Pertama Pada Masa Pandemi Covid-19. dari http://eprints.ums.ac.id/90553/1/1.\%20Artikel\%20Publikasi.pdf. diakses pada tanggal 3 Desember 2021.

\section{Data Penulis}

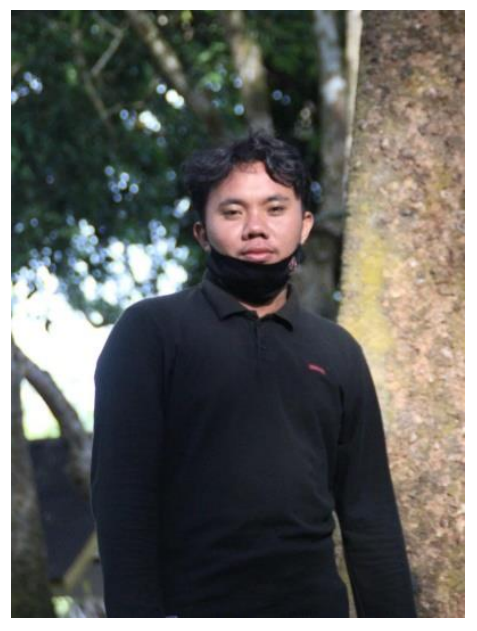

Muhammad Badrul Tamam, lahir di Selat Panjang, 15 Agustus 2000. Ia merupakan anak ke 4 dari 4 bersaudara. Pada tahun 2019, ia melanjutkan studi Stata 1 di Universitas Riau, Program Studi Pendidikan Bahasa dan Sastra Indonesia melalui jalur SNMPTN (Seleksi Nasional Maksuk Perguruan Tinggi Negeri). Saat ini ia sudah di semester 5 dan juga telah menerbitkan beberapa buku antologi cerpen dan puisi. ia berharap artikelnya ini dapat menjadi acuan dan referensi bagi orang lain yang melakukan penelitian di topik atau tema yang sama.

Kontak :

$\mathrm{Hp} / \mathrm{Wa} \quad: 0822-8639-5530$

Email : m.badrultamamm@gmail.com 